\title{
Conditional Cash Transfer Programs and Electoral Accountability: Evidence from Latin America
}

Nara Pavão

ABSTRACT

Do conditional cash transfer programs reduce voters' incentives to hold their government accountable for its performance? Studies show that these programs generate considerable electoral returns for the governments responsible for them. One important and unexplored question is whether these popular programs have also changed the landscape of accountability in Latin America. Survey data from 16 Latin American countries that have adopted CCT programs do not offer support for the claim that such programs have a detrimental effect on electoral accountability for corruption and for the economy. Only in countries where CCT programs do not follow strict rules do beneficiaries attribute relatively less weight to the government's economic performance, but this effect is marginal. These findings fill an important gap in the literature and offer reassuring evidence that cash transfers can alleviate poverty while preserving voters' incentives to exercise electoral accountability in crucial areas of government performance.

$\mathrm{T}$ he extent to which voters hold governments accountable for their performance and the factors that condition electoral accountability are key issues in the scholarship surrounding the quality of Latin American democracies. Recent work has given us reason to believe that, as in more developed parts of the world, voters in Latin America are able to translate their assessments of government performance into attitudes toward that government. An increasing body of research has supported this argument by showing that governments are not immune to poor economic performance or to corruption (Canache and Allison 2005; Ferraz and Finan 2008; Lewis-Beck and Ratto 2013; Remmer 1991; Singer 2013, among others).

The relatively recent diffusion of conditional cash transfer programs in Latin America has changed the social and political landscape of the region. Besides being the ultimate tool for fighting poverty, this popular policy has also been equally efficient in generating electoral returns for the governments in charge of them (Bohn 2011; De La O 2013; Díaz-Cayeros 2008; Díaz-Cayeros et al. 2016; Hunter and Power 2007; Layton and Smith 2011; Manacorda et al. 2011; Soares and Terron 2008). A clear example of the popularity of CCT programs was observed in Brazil's 2014 elections, when the two major opposition candidates not only explicitly

Nara Pavão is a postdoctoral fellow at the Center for the Study of Democratic Institutions, Vanderbilt University.narapavao@gmail.com 
embraced the Bolsa Família (a program strongly associated with the incumbent government) but also promised to expand it if elected. "Bolsa Familia is 'in' right now and there's no one who'll speak against it," noted Brazil's Ministry of Social Development (Matoso 2014).

In Latin America, social policies have historically assumed the form of clientelism and patronage, which represented a threat to democratic accountability in the region. Conditional cash transfer programs, on the other hand, were vested in technical criteria and in the promise of breaking with the damaging consequences of clientelistic practices. The combination of cash transfers and pro-incumbent electoral returns in a region historically plagued by clientelism raises the possibility that CCT programs might represent a threat to democracy and to political accountability. Some academic attention has been paid to the question of whether CCT programs are manipulated politically or persuade voters to vote against their preferences (De La O 2013; Schedler 2000; Cornelius 2004). A related but largely understudied concern is that CCT programs have altered the landscape of accountability in Latin America, making voters less responsive to their perceptions of government performance regarding key issues such as the economy and corruption.

This important but understudied question not only underlies most studies on the politics of CCT programs, but is also echoed by the press and public opinion in many countries. For instance, the largest CCT program in the world, Brazil's Bolsa Família (family grant), is ironically referred to as Bolsa Votos (vote grant) (Lindert and Vincensini 2010). Some analysts contend that this CCT program has driven poor Brazilian voters to turn a blind eye to charges of corruption against Brazil's former president, Lula da Silva, leading to his re-election in 2006 (Hunter and Power 2007).

Examples of this sort abound beyond Brazil. In Ecuador, the intense debates surrounding the clientelistic character of the country's CCT program, the Bono de Desarrollo Humano (human development grant), makes the media refer to it as Bono de la Discordia (discord grant) (Molina Díaz 2012). In Mexico, the secretary of social assistance acknowledges the need for the country's CCT program Oportunidades to transcend its paternalistic and assistencialist character (Milenio 2013; León 2013). In Colombia, the program Familias en Acción-which is ironically referred to as Dudas en Acción (Semana 2010, 2008) - has been seen as a powerful strategy to win votes (El Espectador 2010). These criticisms suggest that CCT programs turn citizens into clients who are ready to support the government out of narrow self-interest. In this scenario, CCT programs could represent a buffer against governments' poor performance. Is this argument sound?

This article assesses how extensively CCT programs affect accountability for the economy and for corruption. It does so by following three steps. First, it investigates whether cash transfers bias voters' evaluations of how well the government manages the economy and the problem of corruption. Second, it assesses how much CCT programs reduce the weight that beneficiaries attribute to these evaluations when deciding whether or not to support the incumbent. If these hypothesized effects are found to exist, a large share of Latin American voters—according to the sample used 
here, this proportion varies from 5 percent in Peru to 56 percent in Bolivia-largely condition their assessments of the government and their vote choice on receiving CCT benefits, regardless of how well or poorly they believe the government performs. ${ }^{1}$ Furthermore, this study analyzes whether the hypothesized effects of CCT programs are contingent on the strictness of the programs' operational rules.

This study aims to fill important gaps in the literature. Other attempts to understand the politics of CCT programs have been restricted to the study of these programs' design and implementation throughout the world, or to their electoral returns. Despite their indisputable importance, none of these research agendas has fostered a good understanding of how CCT programs change the landscape of accountability in Latin America. Although we know that CCT programs generate electoral returns for the governments in charge of them, the weight of these programs in comparison to other aspects of government performance in shaping voters' behavior remains unknown.

To assess this argument, this study uses survey data from 16 Latin American countries that have adopted CCT programs. The empirical analysis points to some important results. First, CCT programs do not seem to bias voters' perceptions of how well the government manages corruption and the economy. Second, benefiting from a CCT program does not affect voters' willingness to blame the government for corruption or for poor economic performance. The only evidence that CCT programs may affect electoral accountability was found in countries where CCT programs do not follow strict rules. In this context, the evidence suggests that those who benefit from a CCT program weigh government's economic performance less heavily than nonbeneficiaries. Despite its statistical significance, the magnitude of this effect is marginal.

This article represents a first attempt to answer a question that has been raised both in the literature surrounding CCT programs and in the public sphere. The findings presented here complement the existing research on the topic by showing that although CCT programs do generate electoral returns for the governments in charge of them, they do not go so far as to overshadow the electoral consequences of poor government performance in terms of the economy and corruption. This is good news not only for Latin American countries but also for the many regions in the world to which CCT programs have been swiftly exported.

\section{What We Know and Do Not Know (But Should) About CCT Programs}

The first country to adopt some kind of CCT program was Brazil in 1995, followed by Mexico in 1997. Since then, CCT programs have increased in both number and size and are now the fastest-growing social policy in the world (Zucco 2013). In Latin America, they have reached 18 countries and large portions of their societies. In Brazil, for example, the CCT program includes 14 million families, around onefourth of all Brazilians (Portal Brasil 2015).

Such programs are based on the provision of money to poor families, contingent on certain conditionalities, usually these families' commitment to the health 
and education of their children. The innovation of CCT programs relies on this combination of short-term financial assistance and long-term investment in human capital (Rawlings and Rubio 2005). The success of CCT programs is also often attributed to their respective designs. The targeting of benefits, at least in principle, follows technical criteria-through a combination of poverty maps and proxy means tests-and the fulfillment of program conditionalities is subject to strong monitoring as well as evaluation (Rawlings 2004).

The popularity that CCT programs have achieved worldwide and in national contexts has motivated other lines of study that go beyond the evaluation of CCT programs' intended goals. More important, CCT programs originated in Latin America, a region in which social assistance frequently assumes the form of clientelism. Investigating the implementation and political effects of CCT programs became crucial for evaluating how extensively these programs have actually represented an innovation that breaks with traditional clientelistic practices.

Studies that shed light on the politics of CCT programs offer evidence of electoral returns for incumbents in Brazil (Hunter and Power 2007; Licio et al. 2009; Soares and Terron 2008; Zucco and Power 2012; Zucco 2013, 2008), Colombia (Baez et al. 2012), Uruguay (Manacorda et al. 2011), and Mexico (De La O 2013; Díaz-Cayeros et al. 2016). In general, these studies are in line with the argument that reliance on government transfers "provides incentives for voters to support their benefactor" (Zucco 2008, 48). Corrêa (2015), however, contradicts this claim. Indeed, the findings regarding the pro-incumbent electoral returns of CCT programs have reinforced the debate over the implications of these programs for electoral accountability.

Although these studies have advanced our understanding of the politics of CCT programs, they have left important questions unanswered. The finding that CCT programs boost pro-incumbent electoral support—albeit an important one-essentially tells us simply that CCT programs factor into voters' assessments of their government. The electoral importance of CCT programs relative to other aspects of government performance remains unknown. Is the impact of CCT programs on voters' attitudes and behavior strong enough to overshadow voters' perceptions of poor economic performance and corruption?

It is worth mentioning that voters' weighing corruption and poor economic performance less heavily when receiving cash transfers from the government can still be understood in the framework of retrospective voting. The fact that voters reward governments for implementing policies they like-policies that have improved their economic situation—suggests that strategies for ensuring accountability are in place. However, this form of accountability may or may not come at the expense of other important aspects of government performance. Assessing whether cash transfers trump poor economic performance and corruption in shaping voters' attitudes and decisions helps us better understand the tradeoffs voters make and the overall implications of these choices for governance and the quality of Latin American governments. 


\section{Cash Transfers and Accountability FOR THE ECONOMY AND FOR CORRUPTION}

Previous work on public opinion and voting behavior has suggested that - to different extents and for different reasons_-both poor economic performance and corruption drive down levels of support for the incumbent. Voters' ability to punish or reward governments on the basis of their performance is what ensures "accountability representation" (Przeworski et al. 1999). In other words, the possibility of being punished for poor economic performance and for corruption represents an incentive for governments to deliver good economic outcomes and a clean government, two things that voters tend to praise. Recently in Latin America, another very important factor has been shown to affect support for incumbents: government cash transfers to poor families.

We know that voters take account of different aspects of government performance in order to decide their vote (Downs 1957; Echegaray 2005; Fiorina 1981) and that because of cognitive limitations, they tend to overlook certain issues and prioritize others (Iyengar and Kinder 1987; Payne 1976; Redlawsk 2004). Therefore, although government performance can be assessed in multiple dimensions, voters may prefer to strategically ignore one or a few of them while appraising others (Singer 2011b). Instead of caring equally about government performance in all areas, citizens respond more to performance on issues that are salient to them (Edwards et al. 1995). The salience of an issue is defined by its relative importance to voters (Wlezien 2005; Berelson et al. 1954); an issue is salient to a voter if he or she cares a great deal about it. According to this framework, voters' decisions to support a candidate in the polls result from a calculus in which they trade factors they care less about for those they weigh more heavily. This article investigates the extent to which cash transfers reduce the relative electoral weight voters attribute to government performance regarding corruption and the economy.

This study anticipates that CCT programs could affect electoral accountability in two ways: by biasing voters' evaluations of government performance on corruption and the economy, and by reducing the weight voters attribute to these two types of evaluations when forming their attitudes toward the government and when deciding whether to support the incumbent. The existing literature explains why we should expect CCT programs to affect economic and corruption voting and leads us to the hypotheses tested in this article.

\section{CCT Programs and Economic Voting}

Empirical evidence suggests that economic voting exists in Latin America (LewisBeck and Ratto 2013; Remmer, 1991; Singer 2013); that is, voters in the region reward or punish their governments according to the performance of the economy. The economy matters because voters tend to have some interest in the material prospects of their country. Therefore politicians in the region, far from unchecked, are held accountable for the economy. 
For this type of accountability to be in place, voters have to connect their perceptions of how well the government manages the economy with voting decisions. However, these perceptions are seldom unbiased (Anderson 2007). The literature shows that support for the incumbent (Evans and Pickup 2010; Evans and Andersen 2006; Markus 1988; Wlezien et al. 1997) and voters' personal financial experience (Duch et al. 2000; Funk and García-Monet 1997) can also bias voters' perceptions of the economy. Thus, because cash transfers increase support for the incumbent, they may also bias voters' evaluations of the government's economic performance. In addition, this bias could be caused by the improvements in beneficiaries' economic conditions due to cash transfers themselves. Regardless of what drives the bias, the following hypothesis is possible:

H1a. Beneficiaries of CCT programs are more likely than nonbeneficiaries to evaluate more positively the performance of the government in managing the economy.

Furthermore, we know that voters' levels of economic vulnerability determine the extent to which they respond to economic performance (Fossati 2014; Singer 2013; Hellwig 2001). The economy matters more to voters whose income is more vulnerable to changes in macroeconomic performance. In line with this argument, some studies find that voters' electoral responses to the state of the economy are contingent on the existence of welfare programs that reduce individuals' exposure to economic risks (Pacek and Radcliff 1995; Singer 2011a).

A similar expectation can be drawn for CCT programs. These programs represent a rather popular social policy that provides beneficiaries with direct financial aid, as well as indirect, long-term returns related to education and health. CCT programs serve as safety nets, protecting citizens from economic fluctuations. Therefore, we have reason to expect that those who receive cash transfers from the government will be less likely to be vulnerable to economic fluctuations than those who do not receive the same benefits, and thus to respond less to government economic performance.

Based on this discussion, we have reason to expect CCT programs to moderate the negative impact evaluations of the economy have on government approval and on the decision to support the incumbent. These expectations are translated into the following hypothesis:

H2a. Beneficiaries of CCT programs weigh the government's economic performance less heavily than nonbeneficiaries when evaluating the government and when deciding to vote for the incumbent party.

The arguments that CCT programs-for the reasons just discussed-bias voters' perceptions of the economy and reduce the salience of the national economy in voters' minds are intuitive. After all, cash transfers have a direct impact on voters' economic well-being, making it less dependent on the performance of the national economy. However, do CCT programs bias voters' perceptions and affect the weight voters attribute to noneconomic aspects of government performance? To 
better understand the extent to which CCT programs really affect how voters hold their governments accountable for important factors that go beyond economic concerns, this study also investigates whether these programs affect the weight voters place on corruption when evaluating the government.

\section{CCT Programs and Corruption Voting}

Although the issue of corruption seems to be far less pronounced than the economy in the minds of Latin American voters (Singer 2013), it is one of the most prominent political problems in the region (Weyland 1998). Accountability for corruption is one of the biggest challenges that developing countries face, and not only those in Latin America. Corruption voting refers to how corruption affects incumbent support. If corruption voting exists, voters who perceive corruption as widespread or limited will punish or reward the government in the polls. When corruption voting exists, governments are held accountable for their behavior.

A generally accepted definition of corruption describes it as "a behavior which deviates from the formal duties of a public role because of private-regarding (personal, close family, private clique) pecuniary or status gain; or violates rules against the exercise of certain types of private-regarding influence" (Nye 1967). Citizens may perceive such behavior to be a deviation from the public role that politicians are popularly elected to fulfill. Because politicians are expected to represent citizens' interests and not their own, corruption erodes the link between citizens and politicians, presenting a threat to democracy (Canache and Allison 2005). Indeed, there is strong evidence of the negative impact of corruption on citizens' political attitudes, such as perceived regime legitimacy (Booth and Seligson 2009; Della Porta 2000; Seligson 2006, 2002), evaluation of the incumbent government (Canache and Allison 2005), and trust in government (Bowler and Karp 2004; Morris 1991; Morris and Klesner 2010). ${ }^{2}$ Because voters hold politicians accountable for their behavior, high perception of political corruption should lead to disapproval of the government (Zechmeister and Zizumbo-Colunga 2013).

However, far from being objective assessments, voters' perceptions of how well the government deals with corruption are themselves embedded in broader attitudes toward the government (Anduiza et al. 2013; Davis et al. 2004; Manzetti and Rosas 2015; Rosas and Manzetti 2015). In fact, Grimes and Wängnerud (2010) use data from Mexico to show that perceptions of corruption in the public sector are lower in states with a larger share of households benefiting from the CCT program. If CCT programs in fact shape voters' political allegiance to the government, we should also expect them to bias voters' assessments of how well the government deals with the problem of corruption.

H1b. Beneficiaries of CCT programs are more likely than nonbeneficiaries to evaluate more positively the performance of the government in dealing with corruption.

However, although we would expect corruption-related government performance to have a negative impact on voters' attitudes toward the government, some 
studies suggest that this is not always the case. Anderson and Tverdova (2003) and Chang and Kerr (2009) argue that political allegiances neutralize the impact of corruption on voters' attitudes toward the political system. In a recent paper, Zechmeister and Zizumbo-Colunga (2013) show that the negative effect of perceived corruption on political support is contingent on voters' collective economic conditions. Therefore, under certain circumstances, voters do not translate their perceptions of corruption into attitudes toward the government (Canache and Allison 2005; Kinder 1998; Odugbemi and Lee 2011; Taber and Young 2011). In other words, voters are willing to trade corruption for other aspects of government performance about which they care more (Rundquist et al. 1977).

Because corruption is only one of the many things voters care about when deciding their vote, voters may trade corruption for material well-being (FernándezVázquez et al. 2015; Manzetti and Wilson 2007; Rundquist et al. 1977). To develop this argument, I test the hypothesis that beneficiaries of CCT programs weigh corruption less heavily than nonbeneficiaries in both their assessments of government performance and their decisions to support the government.

H2b. Beneficiaries of CCT programs weigh corruption-related government performance less heavily than nonbeneficiaries when evaluating the government and when deciding to vote for the incumbent party.

\section{CCT Programs' Operational Rules}

A significant part of the literature on CCT programs has evaluated the programs' operational rules, identifying whether cash transfers indeed follow technical criteria or are instead politically manipulated by governments. The results are mixed and context-specific. While studies offer evidence that Brazil's CCT program is insulated from political manipulation (Fried 2012; Soares et al. 2010; Sugiyama and Hunter 2013), other studies show that CCT programs in other countries do not always meet their goal (Díaz-Cayeros et al. 2016; Winters 2010).

The expansion of CCT programs throughout the world has made the diversity of these programs' designs more obvious. De La O (2015) attempts to explain variation in CCT programs' operational rules and offers a classification of programs according to the strictness of these rules. According to De La O, programs that follow strict operational rules (i.e., rules that suppress political discretion) are less prone to political manipulation. When these rules are less strict, programs are more likely to be politicized, which in turn hinders beneficiaries' ability to hold their respective governments accountable.

To better understand the role of CCT programs in hindering electoral accountability, it is important to take these differences into account. It is possible that the effects of CCT programs on voters' incentives to hold their government accountable for corruption and for the economy are contingent on whether the programs follow strict rules or not. Programs with less-strict rules are more prone to political manipulation, which in turn may hinder the nondiscretionary character of CCT programs. 
One could argue that when programs follow discretionary rules, voters are more likely to perceive cash transfers as contingent on political support. If that is the case, those who benefit from CCT programs would feel more indebted and would therefore have more incentives to support their "benefactor" regardless of the politician's actual performance. On the other hand, if programs follow strict, technical rules (i.e., if they are not politically manipulated by governments), voters will be less likely to feel the need to support the government in order to receive the benefit. In this scenario, evaluations of government performance, as well as the impact of these evaluations on support for the incumbent, are likely to be dissociated from receiving cash transfers.

In short, the moderating role of CCT programs is likely to be weaker when programs are guided by strict operational rules and stronger when programs follow lessstrict rules. If this argument is correct-and CCT programs' operational rules do, in fact, matter to beneficiaries-we should be more likely to observe CCT programs defining the extent to which voters punish their governments for corruption or for poor economic performance in countries where programs do not follow strict rules. ${ }^{3}$ To test this argument, I build on De La O's 2015 classification of CCT programs' operational rules.

\section{DATA AND Methods}

The individual-level data employed here come from the AmericasBarometer survey conducted biennially in Latin America and the Caribbean by the Latin American Public Opinion Project (LAPOP 2014). The merged dataset includes 25,830 interviews conducted in 2014 in 16 presidential systems that have adopted CCT Programs: Argentina, Bolivia, Brazil, Chile, Colombia, Costa Rica, Dominican Republic, Ecuador, El Salvador, Guatemala, Honduras, Mexico, Panama, Paraguay, Peru, and Uruguay. ${ }^{4}$ The LAPOP project has the advantage of being one of the few public opinion datasets that include a question on CCT programs, and the only one available that lends itself to comparing the effects of CCT programs on political attitudes in a considerable number of countries.

\section{Method}

The observational nature of the data employed here poses undeniable problems for causal analysis. Because CCT programs target the poor, it is very difficult to isolate the effects of benefiting from a CCT program from the general condition of being poor. The ideal research design would randomly assign individuals to CCT programs, ensuring balanced covariates across treatment and control groups.

However, because this ideal design is not feasible, I rely on a matching method to tease out the causal effect of CCT programs. This methodological approach has become a common tool for estimating causal treatment effects in nonrandomized studies. Given the lack of randomization, matching procedures help maximize the balance of multiple covariates across comparison groups. I employ coarsened exact 
matching (Blackwell et al. 2009; Iacus et al. 2009) to eliminate significant differences between beneficiaries and nonbeneficiaries of CCT programs. Matching algorithms define two groups of survey respondents who are matched to have the same values across all covariates. More specifically, coarsened exact matching selects out a new, more balanced sample across treatment (CCT) and control (not CCT). ${ }^{5}$ The only difference between their observed characteristics is participation in the CCT program. It is important to note that although this design aims to approximate the condition "as if" participation in CCT programs were randomly assigned, it cannot address potential bias caused by unobserved confounders. However, given the observational nature of the data employed here, this strategy represents a significant step toward reducing systematic bias caused by observed variables. ${ }^{6}$

The methodological approach employed here takes into account both the hierarchical structure of the data and the differences in the programmatic requirements for receiving CCT benefits across the countries in the sample. In order to capture differences in the selection process of the CCT programs analyzed, as well as to achieve balance on key covariates between treatment and control in each country, I restrict the matching within each country (Thoemmes and West 2011; McCormick et al. 2013; Arpino and Mealli 2011). Coarsened exact matching generates weights that are then implemented in fixed-effects models with all the appropriate controls to adjust for any remaining imbalance (Ho et al. 2007).

The analysis consists of three steps: first, implementing coarsened exact matching to generate the weights necessary to balance the data; second, checking the balance of the data; and third, running weighted fixed-effects models to estimate the effects of CCT programs. Three types of analyses are presented. First, I examine how much being a beneficiary from a CCT program biases individuals' perceptions of corruption and of the national economy. Second, I assess whether benefiting from a CCT program moderates the negative impact of corruption and of poor economic performance on both evaluations of presidential performance and intentions to support the incumbent. ${ }^{7}$ Then I group the countries included in the analysis according to whether their CCT programs follow strict rules or not and run the interacted models in these two sets of countries.

\section{Variables}

The key dependent variables are presidential approval and intention to vote for the incumbent president or his or her party. The original variable that taps presidential approval was coded so that high values represent positive evaluations. ${ }^{8}$ Intention to vote for the incumbent is based on a variable that asks respondents what they would do if elections were held this week. ${ }^{9}$ Answers were recoded into a dichotomous variable in which 1 represents a respondent's intention to vote for the incumbent candidate or party and zero signals a respondent's intention to support a different party from the current administration. ${ }^{10}$

The two main independent variables employed in this study are individuals' evaluations of government performance regarding the economy and corruption. 
Respondents were asked to evaluate, on a scale of 1 to 7 points, the performance of the current administrations in fighting corruption and managing the economy well. ${ }^{11} \mathrm{~A}$ high score represents a positive evaluation. As a robustness check on the results, online appendix E contains replications of the analysis using two different independent variables: perceptions of whether the national economy has improved and of how widespread corruption is among public officials. Instead of asking specifically about government performance regarding these issues, the question asks respondents to evaluate these issues more broadly.

Although these represent traditional measures that are more frequently employed in studies of economic and corruption voting, the question on how widespread corruption is was not asked in Brazil, Chile, or Costa Rica. To avoid excluding these three countries from the main analysis, I decided to present here the models that use the performance questions (full sample) and move the models that include evaluations of the economy and of corruption (sample without Brazil, Chile, and Costa Rica) to the appendix. As the analyses in appendix E show, similar results are obtained when this different set of questions is included and the sample is reduced.

The central moderating variable in this study is whether or not respondents belong to a CCT program. For all 16 countries included in this analysis, LAPOP's questionnaire contains a question regarding respondents' participation in each country's specific CCT program. ${ }^{12}$ A complete list with the names of and basic descriptive information on the CCT programs in all 16 countries of the sample is included in appendix B. In methodological terms, a moderator, such as belonging to a CCT program, is seen as an additional variable that changes a causal effect. Studying a moderator offers a more refined understanding of a causal relationship (Wu and Zumbo 2008). More specifically, a moderation effect tells us when and for what subgroup in the analysis an independent variable most weakly or strongly causes the dependent variable (Baron and Kenny 1986; Wu and Zumbo 2008).

Drawing from similar models that assess the impact of corruption on political attitudes (Seligson 2002; Zechmeister and Zizumbo-Colunga 2013), the analysis presented here includes controls for standard demographic and socioeconomic variables (gender, age, education, income, rural-urban, and the number of children under 13 years old living in the household). I also use as control a variable (political insider) that defines individuals' political allegiances to their government: sympathizing with the political party in power or having voted for the winner in the most recent presidential election (Anderson and Guillory 1997; Anderson and LoTempio 2002; Ginsberg and Weissberg 1978; Nadeau and Blais 1993). ${ }^{13}$ This variable takes the value of 1 if the respondent either sympathizes with or has voted for the incumbent party, and 0 otherwise. ${ }^{14}$

Finally, in order to assess whether the moderating effect of CCT programs is contingent on whether these programs follow strict operational rules or not, I follow the classification offered by De $\mathrm{LaO}$ (2015). This classification excludes three countries in our sample: Guatemala, El Salvador, and Honduras. ${ }^{15}$ Of the remaining 13 countries analyzed, the CCT programs in Mexico, Colombia, Ecuador, Peru, 
Table 1. Effects of CCT Programs on Perceptions of the National Economy and Corruption

\begin{tabular}{lcc}
\hline \hline & 1 & 2 \\
& Performance Economy & Performance Corruption \\
\hline CCT & -0.0486 & 0.104 \\
Education & $(0.089)$ & $(0.095)$ \\
& $-0.0118^{* *}$ & $-0.0286^{* * *}$ \\
Male & $(0.004)$ & $(0.005)$ \\
& $0.102^{* *}$ & -0.0118 \\
Age & $(0.035)$ & $(0.036)$ \\
& -0.000237 & $-0.00568^{* * *}$ \\
Income & $(0.001)$ & $(0.001)$ \\
& $0.00890^{*}$ & $0.00855^{+}$ \\
Children 13 & $(0.004)$ & $(0.004)$ \\
\multirow{2}{*}{ Urban } & -0.000630 & -0.0125 \\
& $(0.016)$ & $(0.015)$ \\
Political Insider & $-0.169^{* * *}$ & $-0.117^{* *}$ \\
& $(0.043)$ & $(0.044)$ \\
_cons & $0.824^{* * *}$ & $0.777^{* * *}$ \\
$N$ & $(0.037)$ & $(0.037)$ \\
Countries & $2.758^{* * *}$ & $3.432^{* * *}$ \\
Model type & $(0.121)$ & $(0.121)$ \\
\hline \hline
\end{tabular}

${ }^{+} \mathrm{p}<0.10,{ }^{*} \mathrm{p}<0.05,{ }^{* *} \mathrm{p}<0.01,{ }^{* * *} \mathrm{p}<0.001$

Standard errors in parentheses

Paraguay, Chile, and Brazil follow stricter rules, while Costa Rica, Panama, Bolivia, Uruguay, Argentina, and the Dominican Republic have programs that follow lessstrict rules. ${ }^{16}$

\section{AnAlysis AND Results}

The coarsened exact matching relied on the following variables to balance the data: education, gender, income, age, number of children under 13 years old, urban, and political insider. The two continuous variables, age and children under 13, were coarsened to facilitate the matching procedure. This technique yielded successful balancing of the data and generated weights that are implemented in the hierarchical models presented here. See appendix $\mathrm{C}$ for the relevant balance tests.

To recap, the first set of hypotheses (hypotheses $1 \mathrm{a}$ and $1 \mathrm{~b}$ ) state that voters who benefit from CCT programs are more likely than nonbeneficiaries to hold positive evaluations of government performance as regards the economy and corrup- 
tion. It is interesting that in model 1 the coefficient of CCT programs is negative, suggesting that beneficiaries hold more negative views of the government's economic performance (see table 1). However, this coefficient is very small and far from significant. Model 2 finds no evidence that benefiting from CCT programs biases voters' perceptions of how well the government deals with the problem of corruption. Both models suggest that beneficiaries and nonbeneficiaries do not significantly differ in the way they evaluate the performance of the government in dealing with the economy or corruption. Therefore, both models offer no evidence of any perceptual bias generated by cash transfers.

Even if beneficiaries and nonbeneficiaries do not statistically differ in the way they evaluate government performance regarding corruption and the economy, we can still expect them to differ in how they connect these attitudes to their evaluations of the president and their intentions to vote for the incumbent. In other words, CCT program beneficiaries could be less likely than nonbeneficiaries to hold their government accountable for the economy and for corruption. The models in table 2 assess this claim. Models 3 and 4 are the noninteracted ones. They confirm that individuals hold their presidents accountable both for economic performance and corruption. Holding negative evaluations of government performance regarding the economy and corruption decreases both presidential approval rates and the intention to vote for the incumbent.

Furthermore, while beneficiaries and nonbeneficiaries do not significantly differ in how they approve of the government, they seem to differ regarding the likelihood of supporting the incumbent. In line with studies that document the electoral returns for incumbents in many countries, model 4 indicates that beneficiaries of CCT programs are more likely than nonbeneficiaries to declare their vote for the incumbent.

Models 5 and 6 contain interaction terms that allow us to test hypotheses $2 \mathrm{a}$ and $2 \mathrm{~b}$. They show that contrary to what these hypotheses state, CCT programs do not moderate the negative impact of poor government performance regarding the economy and corruption on presidential approval or intention to vote for the incumbent. More specifically, neither of the two interactions in model 5 is significant, which suggests that — controlling for education, gender, income, number of children, urban-rural, and sympathy with the incumbent's political party-receiving cash transfers from the government does not represent an incentive for voters to discount their perceptions of government performance in two key areas when evaluating the president. Similarly, model 6 shows that beneficiaries and nonbeneficiaries do not significantly differ regarding the weight they attribute to economic performance and corruption when deciding their vote.

In order to visualize better the results of models 5 and 6 , the interactions in both models are graphed in figures 1 and $2 .{ }^{17}$ Figure 1 shows the marginal effects of perceptions of economic and corruption performance on presidential approval for those who benefit from CCT programs and those who do not. Figure 2 shows the same marginal effects on intentions to vote for the incumbent. We see that in all four figures, beneficiaries and nonbeneficiaries do not differ significantly in how 
Table 2. CCT Programs and Accountability for the Economy and Corruption (noninteracted and interacted models)

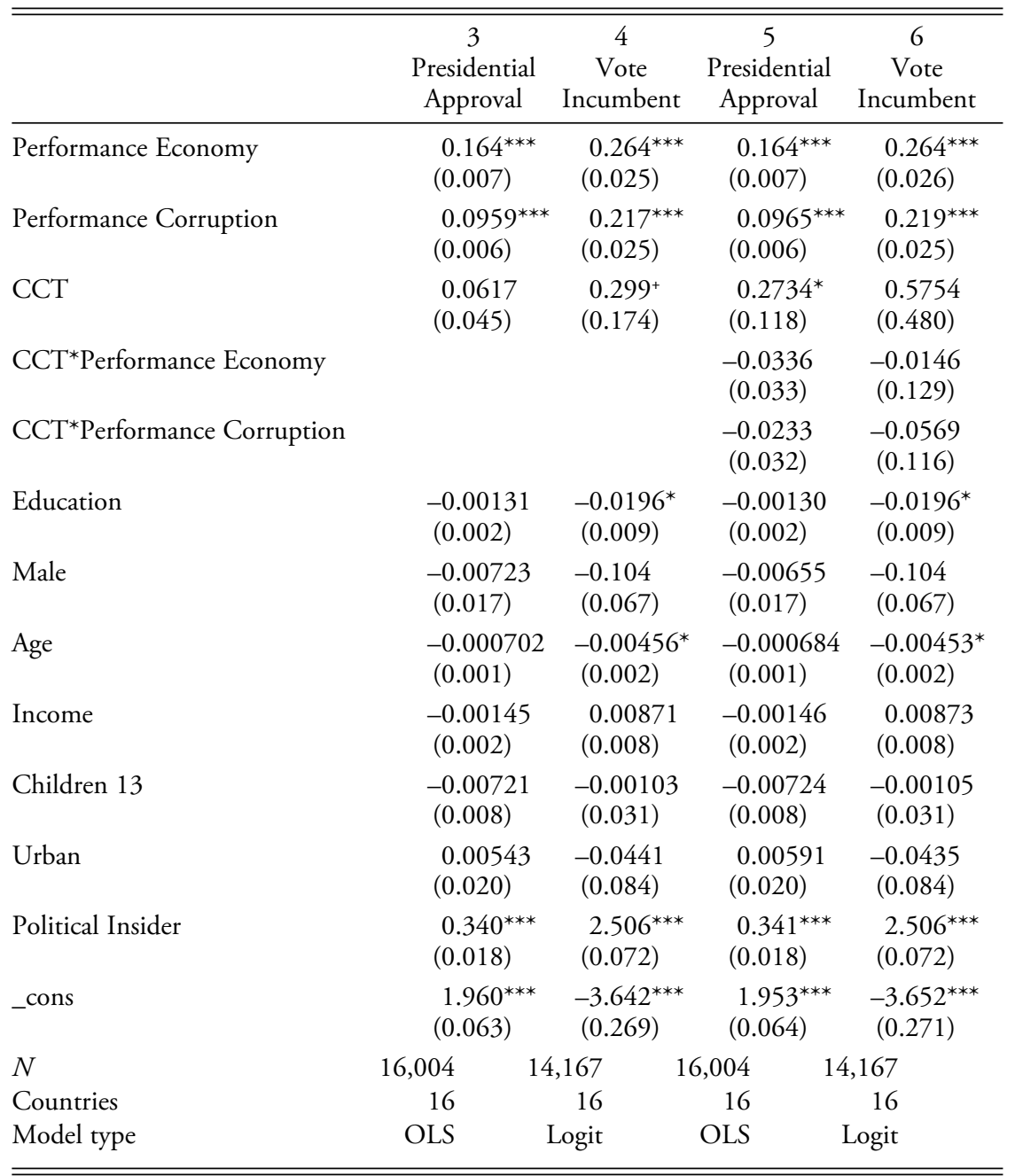

${ }^{+} \mathrm{p}<0.10,{ }^{*} \mathrm{p}<0.05,{ }^{* *} \mathrm{p}<0.01,{ }^{* * *} \mathrm{p}<0.001$

Standard errors in parentheses

they translate perceptions of government performance regarding corruption and the economy into evaluations of the government or intentions to vote for the incumbent. This reflects the lack of significance of the interactions CCT*Performance Economy and CCT*Performance Corruption in both models.

In sum, the results presented here suggest that cash transfers do not reduce the weight voters attribute to poor management of the economy or corruption. How- 
Figure 1. Effect of Evaluations of Government Performance on the Economy and Corruption on Presidential Approval by Beneficiaries and Nonbeneficiaries

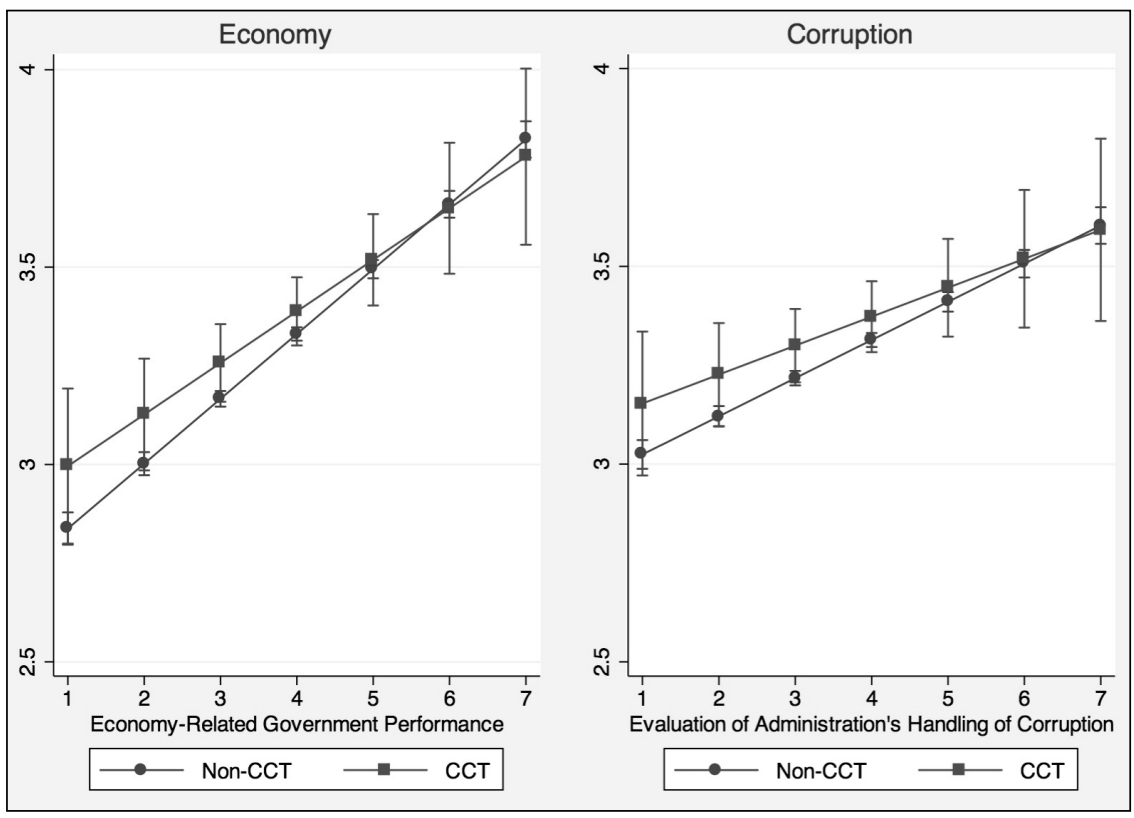

ever, as discussed previously, it is possible that the effects of CCT programs on voters' incentives to hold their government accountable are more prevalent in countries where CCT programs do not follow strict rules. The first set of models (omitted from the main text due to limited space but fully reported in appendix D) replicates noninteracted models 3 and 4 above for countries whose CCT programs follow these two distinct types of operational rules. While negative performance on the economy and corruption affects government approval and vote choice regardless of how strict the programs' rules are, the direct effect of CCT on vote choice is contingent on these rules. More specifically, beneficiaries are more likely than nonbeneficiaries to vote for the incumbent only in the set of countries whose CCT programs follow less-strict rules. Therefore, instead of a finding about CCT programs in general (as the results of model 4 suggest), this evidence indicates that the nature of the CCT program may condition the relationship between beneficiaries and the governments that provide the cash transfers.

Models 7 and 8 (table 3) predict government approval in countries where CCT programs follow, respectively, strict and nonstrict rules. Models 9 and 10 predict intention to vote for the incumbent for countries where CCT programs follow, respectively, strict and nonstrict rules. The only significant interaction (CCT* Performance Economy) is found in model 7, which includes only countries whose CCT programs do not follow strict rules. This evidence suggests that in this set of countries, those who benefit from CCT programs are actually less likely than non- 
Figure 2. Effect of Evaluations of Government Performance on the Economy and Corruption on Vote for the Incumbent by Beneficiaries and Nonbeneficiaries

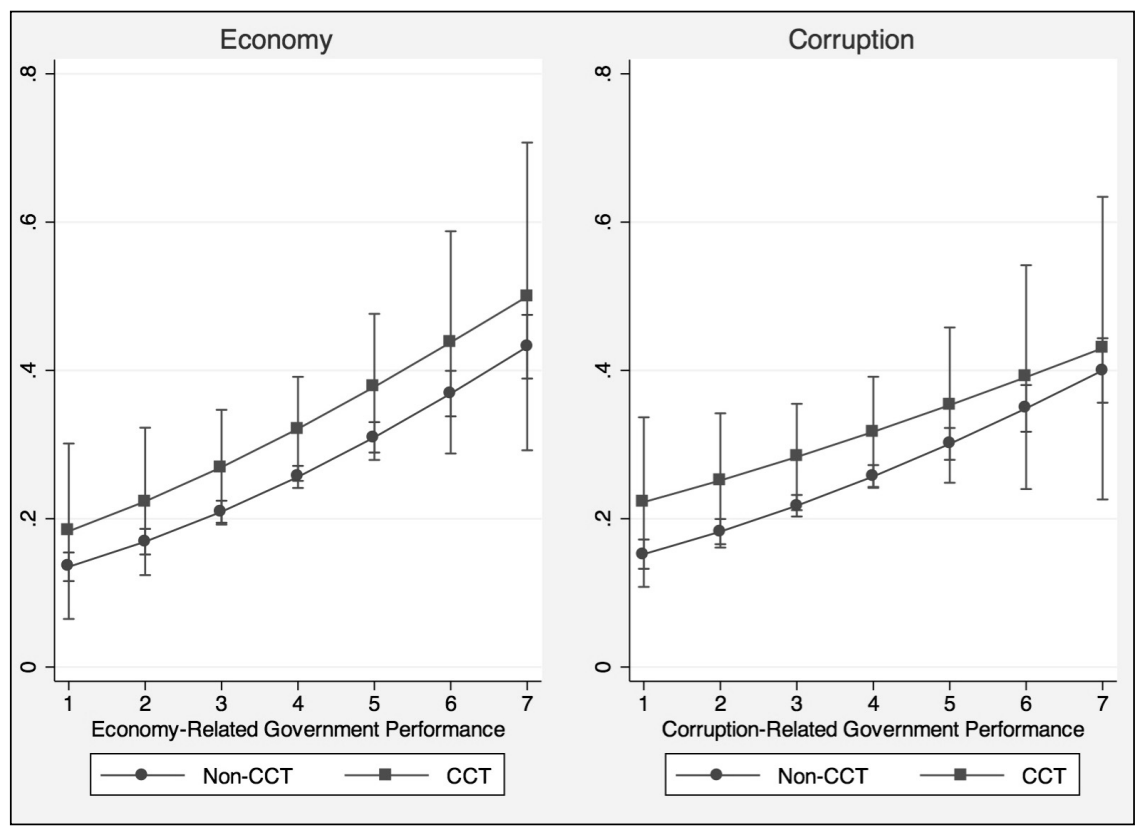

beneficiaries to translate poor economic performance into negative evaluations of the government.

Two interesting trends can be noted. First, a similar effect is not found in the model that predicts vote for the incumbent. This suggests that even though benefiting from CCT programs seems to moderate the negative impact of poor economic performance on government approval, it does not go so far as to affect voters' intentions to support the government in the polls. Second, a moderating effect of cash transfers was not found in either of the two models that include countries whose programs follow strict rules.

To illustrate the effects captured by the statistically significant interaction in model 7 , the two graphs in figure 3 compare the effect of economic performance on government approval for countries whose CCT programs do not follow strict rules (lefthand graph) and follow strict rules (righthand graph). As models 7 and 8 indicate, the slopes for beneficiaries and nonbeneficiaries differ more clearly in the first scenario than in the second. It is important to note that although the difference in slopes displayed in the lefthand figure (not strict) is statistically significant, it is not substantively large. 
Table 3. CCT Programs and Accountability for the Economy and for Corruption in Countries Whose CCT Programs Follow Strict or Not Strict Rules

\begin{tabular}{|c|c|c|c|c|}
\hline & \multicolumn{2}{|c|}{ Presidential Approval } & \multicolumn{2}{|c|}{ Vote Incumbent } \\
\hline & $\begin{array}{c}7 \\
\text { Not Strict }\end{array}$ & $\begin{array}{c}8 \\
\text { Strict }\end{array}$ & $\begin{array}{c}9 \\
\text { Not Strict }\end{array}$ & $\begin{array}{c}10 \\
\text { Strict }\end{array}$ \\
\hline Performance Economy & $\begin{array}{l}0.173^{* * *} \\
(0.012)\end{array}$ & $\begin{array}{l}0.176^{* * *} \\
(0.011)\end{array}$ & $\begin{array}{l}0.293^{* * *} \\
(0.045)\end{array}$ & $\begin{array}{l}0.247^{* * *} \\
(0.040)\end{array}$ \\
\hline Performance Corruption & $\begin{array}{l}0.106^{* * *} \\
(0.012)\end{array}$ & $\begin{array}{l}0.0790^{* * *} \\
(0.010)\end{array}$ & $\begin{array}{l}0.277^{* * *} \\
(0.044)\end{array}$ & $\begin{array}{l}0.215^{* * *} \\
(0.040)\end{array}$ \\
\hline CCT & $\begin{array}{c}0.507^{*} \\
(0.204)\end{array}$ & $\begin{array}{c}0.213 \\
(0.174)\end{array}$ & $\begin{array}{c}1.333 \\
(0.816)\end{array}$ & $\begin{array}{c}0.182 \\
(0.709)\end{array}$ \\
\hline CCT*Performance Economy & $\begin{array}{c}-0.0836^{+} \\
(0.048)\end{array}$ & $\begin{array}{c}-0.0328 \\
(0.062)\end{array}$ & $\begin{array}{c}-0.215 \\
(0.216)\end{array}$ & $\begin{array}{c}0.200 \\
(0.199)\end{array}$ \\
\hline CCT*Performance Corruption & $\begin{array}{c}-0.0313 \\
(0.046)\end{array}$ & $\begin{array}{l}0.000772 \\
(0.056)\end{array}$ & $\begin{array}{c}0.0686 \\
(0.190)\end{array}$ & $\begin{array}{c}-0.231 \\
(0.160)\end{array}$ \\
\hline Education & $\begin{array}{l}-0.000649 \\
(0.004)\end{array}$ & $\begin{array}{l}-0.00517 \\
(0.003)\end{array}$ & $\begin{array}{c}-0.0241 \\
(0.015)\end{array}$ & $\begin{array}{c}-0.0210 \\
(0.013)\end{array}$ \\
\hline Male & $\begin{array}{l}0.00214 \\
(0.029)\end{array}$ & $\begin{array}{c}-0.0233 \\
(0.027)\end{array}$ & $\begin{array}{r}-0.200^{+} \\
(0.114)\end{array}$ & $\begin{array}{r}-0.173^{+} \\
(0.105)\end{array}$ \\
\hline Age & $\begin{array}{l}-0.000128 \\
(0.001)\end{array}$ & $\begin{array}{l}-0.000186 \\
(0.001)\end{array}$ & $\begin{array}{l}-0.0128^{* * *} \\
(0.004)\end{array}$ & * $\begin{array}{l}0.00319 \\
(0.004)\end{array}$ \\
\hline Income & $\begin{array}{l}0.000911 \\
(0.003)\end{array}$ & $\begin{array}{l}-0.00574 \\
(0.004)\end{array}$ & $\begin{array}{l}0.00208 \\
(0.015)\end{array}$ & $\begin{array}{l}-0.00518 \\
(0.014)\end{array}$ \\
\hline Children 13 & $\begin{array}{c}-0.0202 \\
(0.016)\end{array}$ & $\begin{array}{l}-0.00625 \\
(0.012)\end{array}$ & $\begin{array}{r}-0.108^{*} \\
(0.055)\end{array}$ & $\begin{array}{c}0.0202 \\
(0.052)\end{array}$ \\
\hline Urban & $\begin{array}{c}0.0294 \\
(0.035)\end{array}$ & $\begin{array}{c}-0.0135 \\
(0.034)\end{array}$ & $\begin{array}{c}-0.308^{*} \\
(0.144)\end{array}$ & $\begin{array}{c}0.0386 \\
(0.138)\end{array}$ \\
\hline Political Insider & $\begin{array}{l}0.367^{* * *} \\
(0.031)\end{array}$ & $\begin{array}{l}0.316^{* * *} \\
(0.028)\end{array}$ & $\begin{array}{l}2.847^{* * *} \\
(0.118)\end{array}$ & $\begin{array}{l}2.219^{* * *} \\
(0.116)\end{array}$ \\
\hline _cons & $\begin{array}{l}1.508^{* * *} \\
(0.082)\end{array}$ & $\begin{array}{l}2.064^{* * *} \\
(0.091)\end{array}$ & $\begin{array}{l}-2.960^{* * *} \\
(0.311)\end{array}$ & $\begin{array}{l}-3.632^{* * *} \\
(0.362)\end{array}$ \\
\hline$N$ & 5,926 & 6,730 & 5,298 & 5,844 \\
\hline Countries & 6 & 7 & 6 & 7 \\
\hline Model Type & OLS & OLS & Logit & Logit \\
\hline
\end{tabular}

${ }^{+} \mathrm{p}<0.10,{ }^{*} \mathrm{p}<0.05,{ }^{* *} \mathrm{p}<0.01,{ }^{* * *} \mathrm{p}<0.001$

Standard errors in parentheses 
Figure 3. Effect of Evaluations of Government Economic Performance on Government Approval (Nonstrict vs. Strict rules)

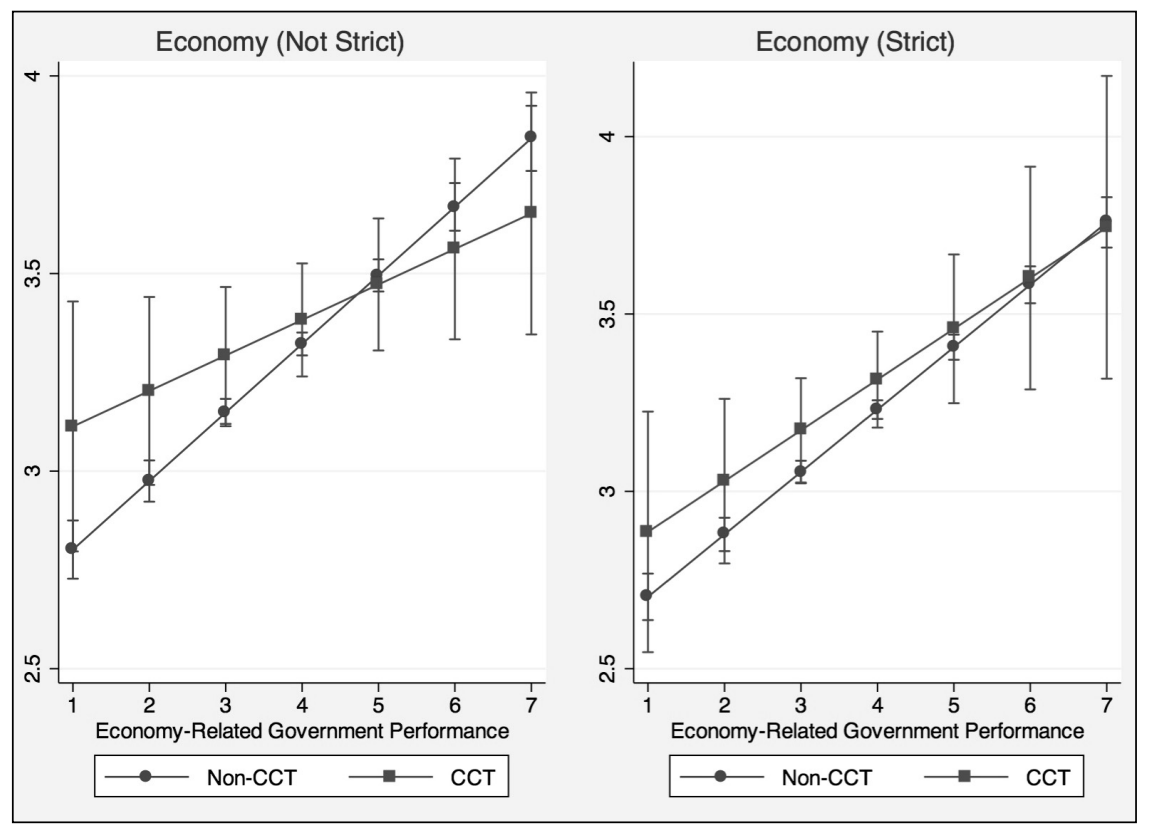

\section{Conclusions}

This study provides evidence that CCT programs do not hinder voters' incentives to hold their government accountable for government performance in handling the economy and corruption. Even though these programs have been shown to generate electoral returns for incumbents, they do not represent an incentive for voters to turn a blind eye to important aspects of government performance.

Benefiting from cash transfers seems to have an effect only among voters in countries whose programs do not follow strict rules. This effect, however, is small and restricted to government approval; i.e., it does not extend to the decision to support the incumbent in the polls. Therefore, these results indicate that in countries where CCT programs do not follow strict rules, even if CCT programs hinder voters' incentives to connect their perceptions of the government's economic performance to their attitudes toward the president, they do not go so far as to induce voters to disregard these perceptions when ultimately deciding their vote.

The lack of more substantive effects of CCT programs on the weight voters attribute to the economy is striking. The debate on the contingent electoral effects of the economy suggests that safety nets reduce the salience of the economy by making voters less dependent on economic fluctuations (Pacek and Radcliff 1995; Singer 2011a). Cash transfers are expected to work in the same way. The absence of 
a stronger effect is probably due to the small value of cash transfers. Instead of serving as the central source of income for poor families, these transfers are designed to alleviate poverty by supplementing poor families' income and at the same time committing them to long-term investments in human capital.

These findings fill a gap in the literature that has tried to understand the indirect political consequences of CCT programs. Although previous studies have offered evidence that voters reward governments for adopting CCT programs, the broad implications of these returns for electoral accountability-whether these programs create captive clienteles (Zucco 2013) or persuade voters to vote against their preferences (De La O 2013; Schedler 2000; Cornelius 2004)—have remained unknown. This study offers a preliminary answer to this concern. In general, the results presented here suggest that CCT programs have not significantly subverted the pattern of accountability found in Latin America and do not shield governments from poor economic performance or from corruption.

CCT programs came with the promise of breaking with the old-fashioned clientelism that prevailed in Latin America for so many decades. The analysis presented in this article shows that CCT programs - unlike clientelism-do not represent a threat to democratic governance or the quality of democracy in Latin America. CCT programs are the fastest-growing social policy in the world (Zucco 2013) and are now present on every continent. In line with Sugiyama and Hunter (2013), this article offers good news to countries beyond Latin America in that it shows that good governance can accompany the fight against poverty.

This study also reinforces the importance of CCT programs' strict operational rules. These rules can represent a safeguard to political accountability. Any damaging effect that CCT programs may have on voters' incentives to hold their "benefactor" accountable may stem from how these programs are managed, rather than from the distribution of cash transfers per se. These insights should serve as further justification for strengthening the operational rules of CCT programs around the world.

\section{NoTES}

I am grateful to Adam Auerbach, Jaimie Bleck, Sandra Botero, Rodrigo Castro-Cornejo, Hilal Jamal, Scott Mainwaring, David Nickerson, Ben Radcliff, Matt Winters, and members of the Comparative Politics Workshop at the University of Notre Dame for their invaluable suggestions and criticisms. I would also like to thank the three anonymous reviewers for their constructive comments. All errors are my own. Supplementary and replication materials can be found at www.narapavao.com/publications-and-working-papers.html

1. For more details on the percentages, see table 1 in appendix B.

2. These studies employ a variety of measures of corruption (from corruption victimization to perception of corruption and corruption scandals) and different types of political attitudes (trust in government, trust in political institutions, support for democracy, and support for incumbents, among others). Moreover, both individual-level and aggregate countrylevel data were employed in these studies.

3. This argument is contingent on the assumption that CCT programs' operational rules matter to voters; i.e., that somehow voters understand when cash transfers are dis- 
tributed according to more or less strict criteria and that this perception changes the way they relate to the government. Sugiyama and Hunter (2013) offer evidence that program design matters to voters, and in a later study, Hunter and Sugiyama (2014) confirm that Brazilian beneficiaries do understand that Bolsa Família is a federal program whose continuation is not contingent on the whims of local politicians. As a focus group participant explained, "It's really a federal program. It's not Tom, Dick, or Harry's. It's federal" (Hunter and Sugiyama 2014, 837). These authors show that beneficiaries of Brazil's CCT program-which, according to Ana de La O's classification (2015), follows strict rulesperceive the cash transfers as a right, not as a favor offered by the government in exchange for votes.

4. The question on membership in CCT programs was only available for these 16 countries, as well as for Jamaica and Trinidad and Tobago. Since these two countries are not presidential democracies, I excluded them from the sample.

5. It does so by generating weights to be used in the estimation of the effects of the variable of interest.

6. The shortcomings of the empirical analysis - in particular those related to unobservable confounders-reflect the limitations of the available (observational) data. The analysis presented here, however, should be understood as a first attempt to analyze a question of both practical and theoretical relevance.

7. It is important to note that while other political actors could also benefit politically from CCT programs, this study focuses on how these programs affect individuals' attitudes toward the president. This focus is in line with most of the specialized literature on CCT programs, which links both the adoption of CCT programs and the electoral returns they generate to presidents.

8. M1. Speaking in general of the current administration, how would you rate the job performance of President [Name current president]? [Read the options] (5) Very good (4) Good (3) Neither good nor bad (fair) (2) Bad (1) Very bad. Figure 1A in Appendix A displays the country means of presidential approval across all countries in the sample.

9. VB20. If the next presidential elections were being held this week, what would you do? [Read options] (1) Wouldn't vote (2) Would vote for the incumbent candidate or party (3) Would vote for a candidate or party different from the current administration (4) Would go to vote but would leave the ballot blank or would purposely cancel my vote (88) DK (98) DA.

10. Figure $2 \mathrm{~A}$ in Appendix $\mathrm{A}$ shows the percentage of the population of each country in the sample that declared the intention to vote for the incumbent.

11. N9. To what extent would you say the current administration combats (fights) government corruption? N15. To what extent would you say that the current administration is managing the economy well?

12. CCT1B. Now, talking specifically about [conditional cash transfers], are you or someone in your house a beneficiary of this program? (1) Yes (2) No (88) DK (98) DA.

13. It is important to acknowledge the possibility that CCT programs themselves may shape individuals' partisanship. To my knowledge, the only work that addresses this argument is a paper by Zucco (2013), who finds that CCT programs have not affected levels of party identification in Brazil.

14. Due to the low levels of partisanship in Latin America and because the question on previous vote choice was invalid in Costa Rica and El Salvador (since the survey was conducted during presidential elections), I decided to create one single variable that tapped party attachment and previous vote choice. This control aims to reduce bias caused by respondents' political allegiances to the government, and the combined variable captures this dimension. 
15. The CCT programs that the LAPOP question refers to in these three countries are relatively new and were not included in Ana de La O's classification.

16. It is important to note that $\mathrm{De} \mathrm{La} O$ classifies a broader sample of programs beyond the 13 countries analyzed in this paper. The programs of the countries included here, relative to the broader sample classified by $\mathrm{De} \mathrm{La} \mathrm{O}$, score high in the index of strictness of operational rules. Therefore, my classification of programs as to whether they follow strict rules or not reflects the level of strictness of each of these 13 programs relative to each other, not taking into account the entire sample of CCT programs in the region.

17. I use the margins command in Stata to generate these graphs. The plots represent adjusted predictions with 95 percent confidence intervals.

\section{REFERENCES}

Anderson, Christopher J. 2007. The End of Economic Voting? Contingency Dilemmas and the Limits of Democratic Accountability. Annual Review of Political Science 10, 1: 27196.

Anderson, Christopher J., and Andrew J. LoTempio. 2002. Winning, Losing and Political Trust in America. British Journal of Political Science 32, 2: 335-51.

Anderson, Christopher J., and Christine A. Guillory. 1997. Political Institutions and Satisfaction with Democracy: A Cross-National Analysis of Consensus and Majoritarian Systems. American Political Science Review 91, 1: 66-81.

Anderson, Christopher J., and Yuliya V. Tverdova. 2003. Corruption, Political Allegiances, and Attitudes Toward Government in Contemporary Democracies. American Journal of Political Science 47, 1: 91-109.

Anduiza, Eva, Aina Gallego, and Jordi Muñoz. 2013. Turning a Blind Eye: Experimental Evidence of Partisan Bias in Attitudes Toward Corruption. Comparative Political Studies 46, 12: 1664-92.

Arpino, Bruno, and Fabrizia Mealli. 2011. The Specification of the Propensity Score in Multilevel Observational Studies. Computational Statistics and Data Analysis 55, 4: 1770-80.

Baez, Javier, Adriana Camacho, Emily Conover, and Román Zárate. 2012. Conditional Cash Transfers, Political Participation, and Voting Behavior. Impact Evaluation series no. 33. Washington, DC: World Bank.

Baron, Reuben M., and David A. Kenny. 1986. The Moderator-Mediator Variable Distinction in Social Psychological Research: Conceptual, Strategic, and Statistical Considerations. Journal of Personality and Social Psychology 51, 6: 1173-82.

Berelson, Bernard R., Paul Lazarsfeld, and William N. McPhee. 1954. Voting: A Study of Opinion Formation in a Presidential Campaign. Chicago: University of Chicago Press.

Blackwell, Matthew, Stefano Iacus, Gary King, and Giuseppe Porro. 2009. Cem: Coarsened Exact Matching in Stata. Stata Journal 9, 4: 524-46.

Bohn, Simone R. 2011. Social Policy and Vote in Brazil: Bolsa Família and the Shifts in Lula's Electoral Base. Latin American Research Review 46, 1: 54-79.

Booth, John A., and Mitchell A. Seligson. 2009. The Legitimacy Puzzle in Latin America: Political Support and Democracy in Eight Nations. Cambridge: Cambridge University Press.

Bowler, Shaun, and Jeffrey A. Karp. 2004. Politicians, Scandals, and Trust in Government. Political Behavior 26, 3: 271-87.

Canache, Damarys, and Michael E. Allison. 2005. Perceptions of Political Corruption in Latin American Democracies. Latin American Politics and Society 47, 3 (Fall): 91-111. 
Chang, Eric, and Nicholas Kerr. 2009. Do Voters Have Different Attitudes Toward Corruption? The Sources and Implications of Popular Perceptions and Tolerance of Political Corruption. Afrobarometer Working Paper 116. www.afrobarometer.org

Cornelius, Wayne A. 2004. Mobilized Voting in the 2000 Elections: The Changing Efficacy of Vote Buying and Coercion in Mexican Electoral Politics. In Mexico's Pivotal Democratic Election: Candidates, Voters, and the Presidential Campaign of 2000, ed. Jorge I. Domínguez and Chappell H. Lawson. Stanford: Stanford University Press. 47-66.

Corrêa, Diego Sanches. 2015. Conditional Cash Transfer Programs, the Economy, and Presidential Elections in Latin America. Latin American Research Review 50, 2: 63-85.

Davis, Charles L., Roderic Ai Camp, and Kenneth M. Coleman. 2004. The Influence of Party Systems on Citizens' Perceptions of Corruption and Electoral Response in Latin America. Comparative Political Studies 37, 6: 677-703.

De La O, Ana L. 2013. Do Conditional Cash Transfers Affect Electoral Behavior? Evidence from a Randomized Experiment in Mexico. American Journal of Political Science 57, 1: 1-14.

. 2015. Crafting Policies to End Poverty in Latin America: The Quiet Transformation. New York: Cambridge University Press.

Della Porta, Donatella. 2000. Social Capital, Beliefs in Government, and Political Corruption. In Disaffected Democracies: What's Troubling the Trilateral Countries? ed. Susan J. Pharr and Robert D. Putnam. Princeton: Princeton University Press. 202-30.

Díaz-Cayeros, Alberto. 2008. Electoral Risk and Redistributive Politics in Mexico and the United States. Studies in Comparative International Development 43, 2: 129-50.

Díaz-Cayeros, Alberto, Frederico Estevez, and Beatriz Magaloni. 2016. The Political Logic of Poverty Relief: Electoral Strategies and Social Policy in Mexico. New York: Cambridge University Press.

Downs, Anthony. 1957. An Economic Theory of Democracy. New York: Harper.

Duch, Raymond M., Harvey D. Palmer, and Christopher J. Anderson. 2000. Heterogeneity in Perceptions of National Economic Conditions. American Journal of Political Science 44, 4: 635-52.

Echegaray, Fabián. 2005. Economic Crises and Electoral Responses in Latin America. Lanham: University Press of America.

Edwards, George C., III, William Mitchell, and Reed Welch. 1995. Explaining Presidential Approval: The Significance of Issue Salience. American Journal of Political Science 39, 1: 108-34.

El Espectador (Bogotá). 2010. Familias en Acción y las elecciones. June 15. www.elespectador. com/impreso/articuloimpreso-208607-familias-accion-y-elecciones.

Evans, Geoffrey, and Robert Andersen. 2006. The Political Conditioning of Economic Perceptions. Journal of Politics 68, 1: 194-207.

Evans, Geoffrey, and Mark Pickup. 2010. Reversing the Causal Arrow: The Political Conditioning of Economic Perceptions in the 2000-2004 U.S. Presidential Election Cycle. Journal of Politics 72, 4: 1236-51.

Fernández-Vázquez, Pablo, Pablo Barberá, and Gonzalo Rivero. 2015. Rooting Out Corruption or Rooting For Corruption? The Heterogeneous Electoral Consequences of Scandals. Political Science Research and Methods. http://journals.cambridge.org/action/display Abstract fromPage $=$ online\&aid $=9876933 \&$ fulltext Type $=$ RA\&fileId $=$ S204984701500 0084

Ferraz, Claudio, and Frederico Finan. 2008. Exposing Corrupt Politicians: The Effects of Brazil's Publicly Released Audits on Electoral Outcomes. Quarterly Journal of Economics 123, 2: 703-45. 
Fiorina, Morris P. 1981. Retrospective Voting in American National Elections. New Haven: Yale University Press.

Fossati, Diego. 2014. Economic Vulnerability and Economic Voting in 14 OECD Countries. European Journal of Political Research 53, 1: 116-35.

Fried, Brian J. 2012. Distributive Politics and Conditional Cash Transfers: The Case of Brazil's Bolsa Família. World Development 40, 5: 1042-53.

Funk, Carolyn L., and Patricia A. García-Monet. 1997. The Relationship Between Personal and National Concerns in Public Perceptions About the Economy. Political Research Quarterly 50, 2: 317-42.

Ginsberg, Benjamin, and Robert Weissberg. 1978. Elections and the Mobilization of Popular Support. American Journal of Political Science 22, 1: 31-55.

Grimes, Marcia, and Lena Wängnerud. 2010. Curbing Corruption Through Social Welfare Reform? The Effects of Mexico's Conditional Cash Transfer Program on Good Government. American Review of Public Administration 40, 6: 671-90.

Hellwig, Timothy T. 2001. Interdependence, Government Constraints, and Economic Voting. Journal of Politics 63, 4: 1141-62.

Ho, Daniel, Kosuke Imai, Gary King, and Elizabeth Stuart. 2007. Matching as Nonparametric Preprocessing for Reducing Model Dependence in Parametric Causal Inference. Political Analysis 15: 199-236.

Hunter, Wendy, and Natasha Borges Sugiyama. 2014. Transforming Subjects into Citizens: Insights from Brazil's Bolsa Família. Perspectives on Politics 12, 4: 829-45.

Hunter, Wendy, and Timothy J. Power. 2007. Rewarding Lula: Executive Power, Social Policy, and the Brazilian Elections of 2006. Latin American Politics and Society 49, 1 (Spring): 1-30.

Iacus, Stefano M., Gary King, and Giuseppe Porro. 2009. Cem: Software for Coarsened Exact Matching. Journal of Statistical Software 30: 1-27.

Iyengar, Shanto, and Donald R. Kinder. 1987. News That Matters: Television and American Opinion. Chicago: University of Chicago Press.

Kinder, Donald R. 1998. Opinion and Action in the Realm of Politics. In The Handbook of Social Psychology, ed. Daniel Todd Gilbert, Susan T. Fiske, and Gardner Lindzey. London: Oxford University Press. 778-867.

Layton, Matthew, and Amy Erica Smith. 2011. Social Assistance Policies and the Presidential Vote in Latin America. AmericasBarometer Insights 66.

León, Mariana. 2013. Se disputan adultos mayores PRI y PRD. El Universal (Mexico City), June 23.

Lewis-Beck, Michael S., and Maria Celeste Ratto. 2013. Economic Voting in Latin America: A General Model. Electoral Studies 32, 3: 489-93.

Licio, Elaine Cristina, Lucio R. Rennó, and Henrique Carlos de O. de Castro. 2009. Bolsa Família e voto na eleição presidencial de 2006: em busca do elo perdido. Opinião Pública 15, 1: 31-54.

Lindert, Kathy, and Vanina Vincensini. 2010. Social Policy, Perceptions, and the Press: An Analysis of the Media's Treatment of Conditional Cash Transfers in Brazil. Social Protection Discussion Paper 1008. Washington, DC: World Bank.

Manacorda, Marco, Edward Miguel, and Andrea Vigorito. 2011. Government Transfers and Political Support. American Economic Journal: Applied Economics 3, 3: 1-28.

Manzetti, Luigi, and Carole J. Wilson. 2007. Why Do Corrupt Governments Maintain Public Support? Comparative Political Studies 40, 8: 949-70. 
Manzetti, Luigi, and Guillermo Rosas. 2015. The Varying Toll of Corruption Perceptions on Pro-Incumbent Vote Choice in Latin America. In The Latin American Voter, ed. Ryan Carlin, Matthew Singer, and Elizabeth J. Zechmeister. Ann Arbor: University of Michigan Press. 300-323.

Markus, Gregory B. 1988. The Impact of Personal and National Economic Conditions on the Presidential Vote: A Pooled Cross-Sectional Analysis. American Journal of Political Science 32, 1: 137-54.

Matoso, Felipe. 2014. Bolsa Família está na moda e não tem quem fale contra, diz ministra. Globo.com, June 5. http://g1.globo.com/politica/noticia/2014/06/bolsa-familia-esta-namoda-e-nao-tem-quem-fale-contra-diz-ministra.html.

McCormick, Meghan P., Erin E. O'Connor, Elise Cappella, and Sandee G. McClowry. 2013. Teacher-child Relationships and Academic Achievement: A Multilevel Propensity Score Model Approach. Journal of School Psychology 51, 5: 611-24.

Milenio (Mexico City). 2013. Dejar atrás paternalismo de oportunidades, pide Robles. July 1. www.milenio.com/politica/Dejar-paternalismo-Oportunidades-pide-Robles_0_108 589455.html.

Molina Díaz, Miguel. 2012. El bono de la discordia. La Republica (Quito), November 24. www.larepublica.ec/blog/opinion/2012/11/24/el-bono-de-la-discordia/

Morris, Stephen D. 1991. Corruption and Politics in Contemporary Mexico. Tuscaloosa: University of Alabama Press.

Morris, Stephen D., and Joseph L. Klesner. 2010. Corruption and Trust: Theoretical Considerations and Evidence from Mexico. Comparative Political Studies 43, 10: 1258-85.

Nadeau, Richard, and Andre Blais. 1993. Accepting the Election Outcome: The Effect of Participation on Losers' Consent. British Journal of Political Science 23, 4: 553-63.

Nye, J. S. 1967. Corruption and Political Development: A Cost-Benefit Analysis. American Political Science Review 61, 2: 417-27.

Odugbemi, Sina, and Taeku Lee, eds. 2011. Accountability Through Public Opinion: From Inertia to Public Action. Washington, DC: World Bank.

Pacek, Alexander C., and Benjamin Radcliff. 1995. Economic Voting and the Welfare State: A Cross-National Analysis. Journal of Politics 57, 1: 44-61.

Payne, John W. 1976. Task Complexity and Contingent Processing in Decision Making: An Information Search and Protocol Analysis. Organizational Behavior and Human Performance 16, 2: 366-87.

Portal Brasil. 2015. Bolsa Família complementa a renda de 14 milhões de famílias em dezembro. December 12. www.brasil.gov.br/cidadania-e-justica/2015/12/bolsa-familiacomplementa-a-renda-de-14-milhoes-de-familias-em-dezembro

Przeworski, Adam, Susan C. Stokes, and Bernard Manin, eds. 1999. Democracy, Accountability, and Representation. Cambridge: Cambridge University Press.

Rawlings, Laura B. 2004. A New Approach to Social Assistance: Latin America's Experience with Conditional Cash Transfer Programs. Social Protection Discussion Paper series, no. 0416. Washington, DC: World Bank.

Rawlings, Laura B., and Gloria M. Rubio. 2005. Evaluating the Impact of Conditional Cash Transfer Programs. World Bank Research Observer 20, 1: 29-55.

Redlawsk, David P. 2004. What Voters Do: Information Search During Election Campaigns. Political Psychology 25, 4: 595-610.

Remmer, Karen L. 1991. The Political Impact of Economic Crisis in Latin America in the 1980s. American Political Science Review 85, 3: 777-800. 
Rosas, Guillermo, and Luigi Manzetti. 2015. Reassessing the Trade-off Hypothesis: How Misery Drives the Corruption Effect on Presidential Approval. Electoral Studies 39: 2638.

Rundquist, Barry S., Gerald S. Strom, and John G. Peters. 1977. Corrupt Politicians and Their Electoral Support: Some Experimental Observations. American Political Science Review 71, 3: 954-63.

Schedler, Andreas. 2000. The Democratic Revelation. Journal of Democracy 11, 4: 5-19.

Seligson, Mitchell A. 2002. The Impact of Corruption on Regime Legitimacy: A Comparative Study of Four Latin American Countries. Journal of Politics 64, 2: 408-33.

. 2006. The Measurement and Impact of Corruption Victimization: Survey Evidence from Latin America. World Development 34, 2: 381-404.

Semana (Bogotá). 2008. Familias en Acción y Sisben por votos. June 6. www.semana.com/ on-line/articulo/familias-accion-sisben-votos/93101-3.

2010. Dudas en acción. June 12. www.semana.com/nacion/articulo/dudas-accion/ 117911-3

Singer, Matthew M. 2011a. Economic Voting and Welfare Programmes: Evidence from the American States. European Journal of Political Research 50, 4 (June): 479-503.

- 2011b. Who Says "It's the Economy"? Cross-National and Cross-Individual Variation in the Salience of Economic Performance. Comparative Political Studies 44, 3 (March): 284-312.

- 2013. Economic Voting in an Era of Non-Crisis: The Changing Electoral Agenda in Latin America, 1982-2010. Comparative Politics 45, 2 (January): 169-85.

Soares, Fábio Veras, Rafael Pérez Ribas, and Rafael Guerreiro Osorio. 2010. Evaluating the Impact of Brazil's Bolsa Família: Cash Transfer Programs in Comparative Perspective. Latin American Research Review 45, 2: 173-90.

Soares, Gláucio Ary Dillon, and Sonia Luiza Terron. 2008. Dois Lulas: a geografia eleitoral da reeleição (explorando conceitos, métodos e técnicas de análise geoespacial). Opinião Pública 14, 2: 269-301.

Sugiyama, Natasha Borges, and Wendy Hunter. 2013. Whither Clientelism? Good Governance and Brazil's Bolsa Família Program. Comparative Politics 46, 1 (October): 43-62.

Taber, Charles, and Everett Young. 2011. Information Processing, Public Opinion, and Accountability. In Odugbemi and Lee 2011. 95-122.

Thoemmes, Felix, and Stephen G. West. 2011. The Use of Propensity Scores for Nonrandomized Designs with Clustered Data. Multivariate Behavioral Research 46: 514-43.

Weyland, Kurt G. 1998. The Politics of Corruption in Latin America. Journal of Democracy 9, 2: 108-21.

Winters, Matthew S. 2010. Exploring Changes over Time in the Targeting of a Cash Transfer Program in Ecuador. Paper presented at the 2010 Midwest Political Science Association Annual Meeting, Chicago, April 6.

Wlezien, Christopher. 2005. On the Salience of Political Issues: The Problem with "Most Important Problem.” Electoral Studies 24, 4: 555-79.

Wlezien, Christopher, Mark Franklin, and Daniel Twiggs. 1997. Economic Perceptions and Vote Choice: Disentangling the Endogeneity. Political Behavior 19, 1: 7-17.

Wu, Amery, and Bruno Zumbo. 2008. Understanding and Using Mediators and Moderators. Social Indicators Research 87, 3: 367-92.

Zechmeister, Elizabeth J., and Daniel Zizumbo-Colunga. 2013. The Varying Political Toll of Concerns About Corruption in Good Versus Bad Economic Times. Comparative Political Studies 46, 10 (October): 1190-1218. 
Zucco, Cesar. 2008. The President's "New" Constituency: Lula and the Pragmatic Vote in Brazil's 2006 Presidential Elections. Journal of Latin American Studies 40, 1: $29-49$.

2013. When Pay Outs Pay Off: Conditional Cash-Transfers and Voting Behavior in Brazil, 2002-2010. American Journal of Political Science 57, 4: 1-13.

Zucco, Cesar, and Timothy Power. 2012. Bolsa Família and the Shift in Lula's Electoral Base, 2002-2006. SSRN Scholarly Paper ID 2025680. Rochester, NY: Social Science Research Network.

\section{SUPPORTING INFORMATION}

Additional supporting materials may be found with the online version of this article at the publisher's website:

1. Appendix-Cash Transfers and Accountability

2. Replication Data-Cash Transfers and Accountability

3. Replication Code-Cash Transfers and Accountability 